\title{
Analysis of the Effect of Competence and Soft Skill on Employee Performance with Job Satisfaction as Intervening Variable at the Regional Social Services of South Tapanuli Regency
}

\author{
Hariawan Ramadhan ${ }^{1}$, Prihatin Lumbanraja ${ }^{2}$, Sukaria Sinulingga ${ }^{3}$ \\ ${ }^{1,2,3}$ Department of Management, University of Sumatera Utara, Medan, Indonesia. \\ Corresponding Author: Hariawan Ramadhan
}

\section{ABSTRACT}

Efforts to improve the performance of local governments are a challenge for regional work units to improve the welfare of local people. The performance of public services in South Tapanuli which still looks unprofessional does not just happen, but is a consequence of the existence of a bureaucratic design that is not prepared as a public servant. Service in the social sector is one form of public service that is very important. Some people who need services complain because the services at the Regional Social Service Office of South Tapanuli Regency are not yet optimal. As a result, the implementation of the main tasks and functions of the Regional Social Service of South Tapanuli Regency cannot be achieved optimally. Therefore, it is important to see how competence and soft skills through satisfaction improve performance at the South Tapanuli Social Service. The purpose of this study was to analyze the effect of competence, soft skills on employee performance through job satisfaction as an intervening variable at the Regional Social Service Office of South Tapanuli Regency. The population of this research is ASN who work in the Regional Social Service of South Tapanuli Regency, amounting to 30 people. Data analysis is descriptive analysis and path analysis using SPSS software. The results showed that competence and soft skills directly had a positive and significant effect on job satisfaction, then competence, soft skills and job satisfaction also had a positive and significant effect on employee performance. Indirectly, job satisfaction is able to positively and
\end{abstract}

significantly mediate the relationship between competence and soft skills variables on employee performance.

Keywords: Competence, Soft Skill, Job Satisfaction, Employee Performance

\section{INTRODUCTION}

Human resources are a very important factor for both private and government organizations. Human resources or employees function as a driving factor for every activity to be carried out. In government agencies, to achieve the desired goals, good management is needed, namely the management of civil servants. Civil Servants (PNS) at the Regional Social Service of South Tapanuli Regency, which are the state apparatus that carry out government in carrying out national development, are the backbone of the government. The smooth running of government and implementation of national development depends on the perfection of the state apparatus, both at the central and regional levels. Efforts to improve the performance of local governments are a challenge for the Regional Apparatus Work Units to be able to improve the welfare of the local people by making good, targeted, and comprehensive work plans and programs. The complexity of the demands of public services must always be balanced with increased professionalism of Human Resources (HR) so as to increase the 
productivity of the performance of an organization or agency. Therefore, human resources who have high competence are needed because expertise or competence will be able to support improving the performance of the apparatus.

Performance is a real behavior that is displayed by everyone as work performance produced by employees in accordance with their role in the organization. Employee performance appraisal aims to ensure the objectivity of employee development which is carried out based on a work performance system and a career system that focuses on the work performance system. The Regional Social Service Office of South Tapanuli Regency is one of the government agencies that are required to have high performance in carrying out their duties and functions in the social sector. Efforts to improve the performance of local governments are a challenge for Regional Apparatus Work Units to be able to improve the welfare of local people by making good, targeted, and comprehensive work plans and programs. The performance of public services in South Tapanuli, which still looks unprofessional, does not just happen as something taken for granted, but is a consequence of the existence of a bureaucratic design that is not prepared as a public servant. According to Melinda (2019), services in the social sector are a very important form of public service. Some people who need services complain because the services at the Regional Social Service Office of South Tapanuli Regency are not yet optimal. As a result, the implementation of the main tasks and functions of the South Tapanuli Regency Social Service could not be achieved. The results of research conducted by Amdani (2018), Samsudin, Azhari (2018), Gultom (2017), Rande (2016), Ridwansyah (2018), Ginanti, Made Galuh (2018), Rudi (2017), the results of the research show that competence significant effect on performance. While research conducted by Anggraeni, Ulfa (2018), Dhermawa et al (2012), the results of his research show that competence has no significant effect on performance.

Research conducted by Manik, Ester (2014), Deswarta (2017), Rudi (2017), the results of his research show that competence has a significant effect on job satisfaction. While research conducted by Iriani Rudlia, Justisia (2016), Wijaya, Satya (2016), the results of his research show that competence has no significant effect on job satisfaction.

Research conducted by Ibrahim, and Boerhannoeddin (2017), the results of his research show that soft skills have a significant effect on performance. While research conducted by Melinda, Mila (2019), the results of his research show that soft skills have no significant effect on performance.

Research conducted by Samsudin, Azhari (2018), Devi (2009), Abiyem (2012), Utomo (2011), the results of his research show that job satisfaction has a significant effect on performance. While the research conducted by Wardhono, Wisnu (2014), Widodo, Slamet (2014), the results of his research show that job satisfaction has no significant effect on performance.

\section{LITERATURE REVIEW Performance}

Human resource performance is a term that comes from the word job performance or actual performance (performance or actual achievement achieved by someone). Performance is the result of work both quality and quantity achieved by HR per unit period of time in carrying out their work duties in accordance with the responsibilities given to them. Mangkunegara (2010) defines performance as the result of work in quality and quantity by an employee in carrying out his duties in accordance with the responsibilities given. According to Sutrisno (2010), performance is a record of the results obtained from certain job functions or certain activities over a certain period of time. 


\section{Competence}

According to Mondy (2008) competence is a broad set of knowledge, skills, traits and behaviors that can be technical, related to interpersonal skills or business-oriented. According to Torang (2013) competence is an ability (skill \& knowledge) to carry out or perform activities/jobs/tasks. Sutrisno (2011) suggests that competence literally comes from the word competence which means skill, ability, and authority. Sutrisno (2011) says competence is something that underlies the characteristics of an individual associated with the results obtained in a job. Sutrisno (2011) explains that the notion of competence in public and private organizations is needed, especially to answer the demands of the organization, where there are very fast changes, the development of very complex and dynamic problems and the uncertainty of the future in the order of people's lives.

\section{Soft Skills}

Understanding soft skills, namely soft skills is a social or sociological term to indicate a person's level of EQ, which consists of a group of personality traits, accepted by society, communication, language, one's habits, friendliness, and optimism that characterize relationships with others. Soft skills are a complement to hard skills (a person's IQ) which are a requirement of a job. Soft skills are skills and life skills, both with oneself, in groups or in society as well as with the Creator. Broadly speaking, soft skills are a combination of intrapersonal and interpersonal skills (Purnami, 2013). Soft skills are a person's skills in dealing with other people (interpersonal skills) and selfregulation skills (personal skills) that are able to develop work results optimally (Iqbal, 2012). Wahyono (2014) that soft skills are defined as personal and interpersonal behavior that develops and maximizes human performance. Soft skills are a person's skills in dealing with other people (Interpersonal skills) and skills in self-regulation (Intrapersonal skills) that are able to develop to work optimally (Islami, 2012:30). Another opinion regarding soft skills is individual skills in the application of skills. real and non-academic (Prastiwi, in Wahyono, 2014). Meanwhile, Basir (2011) states that soft skills are something that is invisible/imaginary/abstract. According to Wahyono (2014) soft skills are invisible abilities needed for success, such as communication skills, honesty/integrity, and others.

\section{Job satisfaction}

Job satisfaction is one of the most important factors to get optimal work results. When someone feels satisfied at work, of course he will try his best with all his abilities to complete his task. Thus, employee productivity will increase optimally. Job satisfaction refers to the general attitude of an individual towards his job. Someone with a high level of job satisfaction shows a positive attitude towards the job, otherwise if someone who is dissatisfied with the job shows a negative attitude towards the job.

According to Hasibuan (2012), job satisfaction is an emotional attitude that is pleasant and loves his job. This attitude is reflected by work morale, discipline, and work performance. Job satisfaction is enjoyed at work, outside work, and a combination of inside and outside work. Sutrisno (2011) states that job satisfaction is an employee's attitude towards work related to work situations, cooperation between employees, rewards received at work, and matters relating to physical and psychological factors.

According to Robbins (2010), job satisfaction is a general attitude towards one's job, which shows the difference between the number of awards that workers receive and the amount they believe they should receive. Winardi (2011) explains that satisfaction is an end condition that arises due to the achievement of certain goals. It is the employee's affective reactions (feelings about) aspects of the work situation. 


\section{MATERIALS \& METHODS}

This type of research is descriptive quantitative. According to Sinulingga (2015), "Descriptive research is a type of research that aims to describe systematically, factually and accurately about the facts and characteristics of a particular object or population. This research was conducted at the Regional Social Service Office of South Tapanuli Regency, which is located in the South Tapanuli Regency Government Office Complex, Jalan Prof. Lafran Pane Sipirok. The population in this study is ASN who work in the Regional Social Service of
South Tapanuli Regency, totaling 30 people. The researcher used saturated sampling. Saturated sampling is a sampling technique when all members of the population are used as samples, or the researcher wants to make generalizations with very small errors. Another term for saturated sample is census, where members of the population are sampled (Sugiyono, 2014). Based on this understanding, the sample of this research is the employees of the Regional Social Service Office of South Tapanuli Regency, totaling 30 respondents. The data processing method uses path analysis with SPSS software.

\section{RESULT AND DISCUSSION}

Table 1: Research Result

\begin{tabular}{|c|c|c|c|c|}
\hline Number & Hypothesis & Positive/Negative & $\begin{array}{l}\text { Significant / } \\
\text { Insignificant }\end{array}$ & Description \\
\hline 1. & Competence has a positive and significant effect on Performance & $\begin{array}{l}\text { Beta }=0.460 \\
\text { (Positive) }\end{array}$ & $\begin{array}{l}0.028<0.05 \\
\text { (Significant) }\end{array}$ & Accepted \\
\hline 2. & Soft Skill has a positive and significant effect on Performance & $\begin{array}{l}\text { Beta }=0,267 \\
\text { (Positive) }\end{array}$ & $\begin{array}{l}0,024<0,05 \\
(\text { Significant })\end{array}$ & Accepted \\
\hline 3. & $\begin{array}{l}\text { Competence has a positive and significant effect on Job } \\
\text { Satisfaction }\end{array}$ & $\begin{array}{l}\text { Beta }=0,947 \\
\text { (Positive) }\end{array}$ & $\begin{array}{l}0,000<0,05 \\
(\text { Significant })\end{array}$ & Accepted \\
\hline 4. & Soft Skill has a positive and significant effect on Job Satisfaction & $\begin{array}{l}\text { Beta }=0,292 \\
\text { (Positive) }\end{array}$ & $\begin{array}{l}(0,033>0,05) \\
(\text { Significant })\end{array}$ & Accepted \\
\hline 5 & $\begin{array}{l}\text { Job Satisfaction has a positive and significant effect on } \\
\text { Performance }\end{array}$ & $\begin{array}{l}\text { Beta }=0,328 \\
\text { (Positive) }\end{array}$ & $\begin{array}{l}0,012<0,05 \\
\text { (Significant) }\end{array}$ & Accepted \\
\hline 6 & $\begin{array}{l}\text { Competence has a significant effect on Performance through Job } \\
\text { Satisfaction }\end{array}$ & $\begin{array}{l}\text { Beta }=0,263 \\
\text { (Positive) }\end{array}$ & $\begin{array}{l}0,025<0,05 \\
(\text { Significant })\end{array}$ & Accepted \\
\hline 7 & $\begin{array}{l}\text { Soft Skill has a significant effect on Performance through Job } \\
\text { Satisfaction }\end{array}$ & $\begin{array}{l}\text { Beta }=0,133 \\
\text { (Positive) }\end{array}$ & $\begin{array}{l}0,044<0,05 \\
\text { (Significant) }\end{array}$ & Accepted \\
\hline
\end{tabular}

\section{The Effect of Competence on Performance}

The first hypothesis states that competence has a positive and significant effect on the performance of the Regional Social Service Office of South Tapanuli Regency. In this case, competence is the cause of performance. Therefore, it is important to pay attention to the competence of employees which will improve the performance of employees. It is said that the better the competence of the employee, the better the performance will be. Employees who have an educational background that is in accordance with their work, are skilled, work according to work standards, have a patient work attitude at work, and are able to adapt to the work environment will certainly produce quality performance. The results of statistical tests show that competence has a positive and significant effect on performance. This research is in line with research by Amdani (2018), Samsudin (2018) and Gultom (2017) where the research states that competence has a positive and significant effect on employee performance.

\section{Effect of Soft Skills on Performance}

The second hypothesis states that Soft skills have a positive and significant effect on the performance of the Regional Social Service Employees of South Tapanuli Regency. This shows that soft skills are also the cause of performance problems, which in this case means that the good or bad performance of the agency is largely determined by the soft skills 
possessed by its employees. Employees who have intrapersonal skills that can regulate themselves, are responsible for their work, are able to build good socialization, and have integrity towards work will produce good performance. This research is in line with research conducted by Ibrahin and Boerhannoeddin (2017), Dalimunthe (2017) which states that soft skills have a positive and significant effect on performance.

\section{The Effect of Competence on Job Satisfaction}

The third hypothesis states that competence has a positive and significant effect on job satisfaction of employees of the Regional Social Service Office of South Tapanuli Regency. In this case, competence is also a problem that affects job satisfaction. Competence itself is one of the factors that cause job satisfaction. This can indicate that the better the competence of the employee, the better the employee's job satisfaction. Based on the results of the study, it is known that competence can affect job satisfaction positively and significantly, if competence increases it will also increase job satisfaction. The results of this study are in line with research conducted by Ester (2014) and Deswarta (2017) which shows that competence has a positive and significant effect on job satisfaction. This is also in accordance with Lawler's theory which states that expertise is part of the input factors that affect job satisfaction or dissatisfaction in Munandar, (2012). Furthermore, this research is supported by Setyaningdiyah, Kertahadi, et al (2013) that competence has a positive effect on job satisfaction, then also Yani Haskas (2013) about the influence of competence and motivation on achievement, appreciation and job satisfaction of lecturers at the health sciences high school in South Sulawesi province.

\section{Effect of Soft Skills on Job Satisfaction}

The fourth hypothesis states that Soft Skills have a positive and significant effect on job satisfaction at the Regional
Social Service Office of South Tapanuli Regency. The role of soft skills is also a cause in job satisfaction. Soft skills themselves are important things that must be owned by employees. Soft skills themselves must have conformity with the field of work of the employee. The expected soft skills in the South Tapanuli Regency Social Service are related to the ability to negotiate, build socialization, self-confidence and others. This is because the Social Service employees often deal with humans, where good soft skills are needed. In this case, it can be interpreted that the better the skills of the Regional Social Service employees of South Tapanuli Regency in dealing with other people and the skills in self-regulation, the more job satisfaction will be. The results of this study are in line with research conducted by Dalimunthe's research (2017) which states that interpersonal relationships have a positive and significant effect on job satisfaction. Furthermore, the results of research by Prakash and Mandela (2013) show that there is a significant influence of soft skills on job satisfaction.

\section{The Effect of Job Satisfaction on Performance}

The fifth hypothesis states that job satisfaction has a positive and significant effect on the performance of the Regional Social Service Office of South Tapanuli Regency. This means that satisfaction is also a problem in employee performance so it can be said that the more employees feel satisfied with the work, the better the employee's performance and vice versa if the employee's job satisfaction decreases, the employee's performance will decrease. Job satisfaction is the factor that most influences the performance of the Regional Social Service Office of South Tapanuli Regency, where employees with a high level of job satisfaction show a positive attitude towards work. The better the employee's job satisfaction can bring up positive traits and attitudes and will make employees work optimally. The results of this study are in line with research 
conducted by Destari (2017) and Samsudin (2018) which show job satisfaction has a positive and significant effect on performance. Although it is only one of the many other influential factors, job satisfaction also affects the level of employee performance. With job satisfaction obtained. It is expected that high employee performance can be achieved by employees.

\section{The Influence of Service Quality on Customer Loyalty through Customer Satisfaction}

The sixth hypothesis states that competence has a positive and significant effect on performance through job satisfaction as an intervening variable at the Regional Social Service Office of South Tapanuli Regency. This shows that the better the competence of the employee, the job satisfaction will increase so that it can have an impact on the better the performance produced by the employee at work. Regional Social Service employees of South Tapanuli Regency who have good competencies such as an educational background that is appropriate to the job, able to complete work according to work standards and have skills in completing and taking action in carrying out tasks, and able to work patiently and adapt to the work environment, thus making employees satisfied because they have good competence, that satisfaction will encourage employee performance. The results show that job satisfaction indicators have an important role in mediating employee performance. This research is in line with research conducted by Made, Mahlia and Maat (2018), Rudi (2017) which states that competence affects performance through job satisfaction.

\section{The Influence of Soft Skills on Performance Through Job Satisfaction}

The seventh hypothesis states that soft skills have a positive and significant effect on performance through job satisfaction as an intervening variable at the
Regional Social Service Office of South Tapanuli Regency. This shows that the better the soft skills possessed by employees, the job satisfaction will increase so that it can have an impact on the better the performance produced by employees at work. Regional Social Service employees of South Tapanuli Regency who have good soft skills such as intrapersonal skills which include being able to be responsible for the assigned tasks, have self-confidence, are able to build socialization among fellow employees, and have integrity at work, and have interpersonal skills which include having leadership spirit at work, able to negotiate to solve problems at work, can work in teams, share information or knowledge with fellow co-workers, and be able to provide good social services so as to make employees satisfied because they have good soft skills, satisfaction is will encourage increased employee performance. The results of this study are in line with research conducted by Ibrahim and Boerhannoeddin (2017) which states that there is a positive and significant influence between soft skills on performance, with the high ability of soft skills possessed by employees will affect their performance which of course will also affect job satisfaction.

\section{CONCLUSION}

Based on the analysis and discussion, several conclusions and suggestions can be drawn as follows:

1. Competence has a positive and significant effect on performance

2. Soft Skill has a positive and significant effect on performance.

3. Competence has a positive and significant effect on job satisfaction

4. Soft skills have a positive and significant effect on job satisfaction

5. Job satisfaction has a positive and significant effect on performance

6. Competence has a positive and significant effect on performance through job satisfaction as an intervening variable 

satisfaction as intervening variable at the regional social services of South Tapanuli Regency.

7. Soft skills have a positive and significant effect on performance through job satisfaction as an intervening variable

\section{Acknowledgement: None}

\section{Conflict of Interest: None}

\section{Source of Funding: None}

\section{REFERENCES}

1. Abiyem Juli S. 2012. "Pengaruh Kepuasan Kerja dan Motivasi Terhadap Kinerja Karyawan dengan Komitmen Organisasional sebagai Variabel Intervening (Studi Pada Karyawan Outsourcing PT Berlian Eka Sakti Tangguh)." Jurnal Mitra Ekonomi dan Manajemen Bisnis, Vol.3, No. 1, April 2012.

2. Anggraeni, Ulfa. 2018. "Analisis Pengaruh Kompetisi Karyawan, Lingkungan Kerjs dan Disiplin Kerja Terhadap Kinerja Karyawan dengan Motivasi Sebagai Variabel Moderasi (Studi Kasus Pada Bank BTN Syariah KC Semarang)". Tesis. Program Pascasarjana Universitas IAIN Salatiga.

3. Amdani, Dodi. $2018 . \quad$ "Pengaruh Kompetensi dan Budaya Organisasi Terhadap Kinerja Karyawan Politeknik Ganesha Medan". Tesis. Program Pascasarjana Universitas Sumatera Utara.

4. Anoraga, Pandji. 2009. Psikologi Kerja, Cetakan Kelima. Jakarta: Rineka Cipta.

5. Arikunto, Suharsimi. 2012. Prosedur Penelitian, Suatu Pendekatan Tehnik dan Prosedur. Jakarta: Rineka Cipta.

6. Basir, S. 2011."Soft Skill vs Hard skill . Jakarta Timur: Kantor Akuntan Publik Syarief Basir dan Rekan.

7. Destari, Yuri. 2017. "Pengaruh Kepuasan Kerja terhadap Kinerja Pegawai dengan Komitmen Organisasi sebagai Variabel Intervening pada Dinas Pertambangan dan Energi Provinsi Sumatera Utara". Tesis. Program Pascasarjana Universitas Sumatera Utara.

8. Dalimunthe, Indayana. 2017. "Pengaruh Hubungan Interpersonal dan Ambiguitas Peran terhadap Kepuasan Kerja serta Dampaknya pada Intention to Leave Karyawan Perusahan Jasa Event Organizer di Kota Medan". Tesis. Program Pascasarjana Universitas Sumatera Utara.

9. Deswarta. 2017. Pengaruh Kompetensi Dan Motivasi Terhadap Kepuasan Kerja Dan Kinerja Dosen Fakultas Tarbiyah Dan Keguruan UIN Sultan Syarif Kasim Riau, Jurnal Valuta Vol. 3 No 1, April 2017.

10. Devi, Eva Kris Diana. 2009. Analisis Pengaruh Kepuasan Kerja dan Motivasi Terhadap Kinerja Karyawan dengan Komitmen Organisasional Sebagai Variabel Intervening (Studi Pada Karyawan Outsourcing PT. Semeru Karya Buana Semarang). Masters Thesis, Program Pasca Sarjana Universitas Diponegoro.

11. Edison, Emron., Anwar, Yohny. \& Komariyah, Imas. (2017). Manajemen Sumber Daya Manusia. Bandung : Alfabeta,cv.

12. Ester Manik, Wiarah. 2014. Pengaruh Kompetensi Dan Kompensasi Terhadap Kepuasan Kerja Serta Implikasinya Pada Kinerja Paramedis Di Rumah Sakit Cibarat Kota Cimahi, Jurnal Ekonomi, Bisnis \& Entrepreneurship Vol. 8, No. 2, Oktober 2014, 62-72.

13. Fajar, Achmad. Hendarman. dan Cantner, Uwe. 2017. Soft skills, hard skills, and individual innovativeness. Eurasia Business and Economics Society 2017.

14. Galuh, Made Ginanti., Muis, Mahlia. dan Pono, Maat. 2018. Pengaruh Kompetensi Karyawan Terhadap Kinerja Dengan Kepuasan Kerja Sebagai Variabel Intervening (Studi Pada PT. Dok Dan Perkapalan Surabaya Bagian Produksi), Hasanuddin Journal of Applied Business and Entrepreneurship.

15. Gultom, Lenny Marlina. 2017. "Pengaruh Kompetensi Jabatan Dan Kepemimpinan Terhadap Kinerja Pegawai Melalui Iklim Organisasi Pada Dinas Pendapatan Pengelolaan Keuangan Dan Aset Daerah Kabupaten Karo". Tesis. Program Pascasarjana Universitas Sumatera Utara.

16. Ghozali, Imam. 2011. Aplikasi Analisis Multivariate dengan Program SPSS. Semarang: Badan Penerbit Universitas Diponegoro

17. Hasibuan, Melayu S.P. 2012. Manajemen Sumber Daya Manusia, Edisi Revisi, Cetakan Keenambelas. Jakarta: Penerbit Bumi Aksara. 
18. Hasibuan, Malayu S.P., 2013. Manajemen Sumber Daya Manusia. Jakarta: Bumi Aksara.

19. Ibrahim, Rosli. And Boerhannoeddin, Ali. 2017. The effect of soft skills and training methodology on employee performance, European Journal of Training and Development Vol.41No.4,2017.

20. Iriani Rudlia, Justisia 2016. Pengaruh Kompetensi dan Kompensasi terhadap Kepuasan Kerja dan Kinerja Pegawai (Studi Kasus Pada Dinas Kelautan dan Perikanan Kabupaten Kepulauan Sangihe ). Jurnal Riset Bisnis dan Manajemen Vol 4 ,No.3, 2016: 257-268

21. Jayasuriya, Rohan., Whittaker, Maxine., Halim, Grace., dan Matineau, Tim. 2012. Rural health workers and their work environment: the role of inter-personal factors on job satisfaction of nurses in rural Papua New Guinea, Jayasuriya et al. BMC Health Services Research 2012, 12:156.

22. Luthan, Fred. 2006. Perilaku Organisasi, Edisi Sepuluh. Yogyakarta: Andi Publisher. Mangkunegara, Anwar Prabu, 2010. Sumber Daya Manusia Perusahaan, Remaja Rosda Karya, Bandung.

23. Mangkunegara, A.A. Anwar Prabu. 2010. Manajemen Sumber Daya Manusia. Bandung: Remaja Rosdakarya.

24. Mangkuprawira, Sjafri. 2011. Manajemen Mutu Sumber Daya Manusia Strategik (edisi kedua). Bogor: Penerbit Galia Indonesia.

25. Melati, Sekar. 2020. "Pengaruh Soft Skill Terhadap Kepuasan Kerja (Studi Pada Pekerja PT. Prakarsa Tiga Wiratama". Repository Universitas Negeri Jakarta.

26. Melinda, Mila. 2019 "Pengaruh Hard Skill dan Soft Skill Terhadap Kinerja Karyawan dengan Komunikasi Sebagai Variabel Intervening Pada Puskesmas Gambok Muaro Sijunjung". Repository Universitas Putra Indonesia.

27. Mondy, R. Waine. 2008. Manajemen Sumber Daya Manusia,Jilid I, Edisi Kesepuluh. Jakarta: Erlangga.

28. Moekijat, 2012. Manajemen Sumber Daya Manusia. Bandung : Mandar Maju.

29. Purnami.'Implementasi Metode Experiental Learning Dalam Pengembangan Softskill Mahasiswa Yang Menunjang Integrasi Teknologi, Manajemen dan Bisnis". Jurnal Penelitian Pendidikan , Magister Manajemen Bisnis, Sekolah Pascasarjana,
Universitas Pendidikan Indonesia. ISSN 1412-565 X Vol. 14 No. 1, April 2013.

30. Rahmadani, Suci Tanjung. 2021. Analisis Pengaruh Keterampilan Komunikasi, Insentif, Dan Lingkungan Kerja Terhadap Kinerja Karyawan PT Jaminan Pembiayaan Askrindo Syariah Di Indonesia Dengan Kepuasan Kerja Sebagai Variabel Intervening. Tesis. Program Pascasarjana Universitas Sumatera Utara. Fakultas Ekonomi dan Bisnis.

31. Rande, Dina. 2016. Pengaruh Kompetensi Terhadap Kinerja Pegawai Pada Dinas Perhubungan, Komunikasi Dan Informatika Kabupaten Mamuju Utara, Jurnal Katalogis, Volume 4 Nomor 2, Februari 2016 hlm 101109.

32. Riduwan dan Engkos Achmad Kuncoro. 2011. Cara Menggunakan dan Memakai Analisi Jalur ( Path Analysis ).Bandung: Alfabeta.

33. Ridwansyah. 2018. "Analisis Pengaruh Motivasi, Kompetensi dan Insentif terhadap Kinerja Pegawai pada PT Sianjur Resort Pengembang Perumahan Oma Deli Medan". Tesis. Program Pascasarjana Universitas Sumatera Utara.

34. Robbins, Stephen P. 2014. Perilaku Organisasi. Jakarta: Prenhallindo.

35. Rudi, Galih Prasyanto. 2017. Pengaruh Kompetensi Karyawan Terhadap Kinerja Dengan Kepuasan Kerja Sebagai Variabel Intervening (Studi Pada PT. Dok Dan Perkapalan Surabaya Bagian Produksi), Jurnal Ilmu Manajemen Volume 5 No 2 Jurusan Manajemen Fakultas Ekonomi Universitas Negeri Surabaya.

36. Samsudin, Azhari. 2018. Pengaruh Kompetensi, Motivasi Dan Kepuasan Kerja Terhadap Kinerja Aparatur Di Dinas Pekerjaan Umum Kabupaten Sigi, Jurnal Katalogis, Volume 6 Nomor 1Januari 2018 hlm 23-29.

37. Samsudin, Sadili, 2010. Manajemen Sumber Daya Manusia, Cetakan Pertama. Bandung: Pustaka Setia, Bandung.

38. Satya, Wijaya. 2016. Pengaruh Kompetensi, Lingkungan Kerja Fisik dan Motivasi Terhadap Kepuasan Kerja Karyawan Pada CV. Jaya Utama Teknik Denpasar. E-Jurnal Manajemen Universitas Udayana Vol 3, No 10.

39. Singh, Prakash. dan Mandela, Nelson. 2013. Influence Of The Leaders' Emotionally Intelligent Behaviours On Their 
Hariawan Ramadhan et.al. Analysis of the effect of competence and soft skill on employee performance with job satisfaction as intervening variable at the regional social services of South Tapanuli Regency.

Employees' Job Satisfaction, International Business \& Economics Research Journal July 2013 Volume 12, Number 7.

40. Sinulingga, Sukaria. 2015. Metodologi Penelitian. USU Press, Medan.

41. Sudarmanto, 2009, Kinerja dan Pengembangan Kompetensi SDM, Teori, Dimensi Pengukuran dan Implementasi dalam Organisasi, Yogyakarta : Pustaka Pelajar.

42. Sugiyono, 2014. Metode Penelitian Administrasi (Pendekatan Kuantitatif, Kualitatif, dan R\&D), Alfabeta, Bandung.

43. Sutrisno. Edy, 2012. Manajemen Sumber Daya Manusia. Kencana Prenada Media Group. Jakararta.

44. Sunyoto, Danang, 2015. Penelitian Sumber Daya Manusia, Jakarta : CAPS.

45. Torang, Syamsir. 2013. Organisasi dan Manajemen (Perilaku, Struktur, Budaya dan Perubahan Organisasi. Alfabeta Bandung.

46. Utomo, Joko, 2012. Pengaruh Motivasi Kerja, Kepuasan Kerja dan Komitmen Organisasi Terhadap Kinerja Pegawai (Studi Pada Pegawai Setda Kabupaten Pati), Jurnal.umk.ac.id Vol 5, No 1 (2011) >
Suwardi ..Translate this page by J Utomo 2012.

47. Wahyono, Budi. 2014. Pengertian Dan Arti Penting Soft Skill.

48. Wibowo, 2016. Manajemen Kinerja, Rajawali Pers, Jakarta.

49. Widodo, Slamet. 2014. "Pengaruh Lingkungan Kerja dan Disiplin Kerja Terhadap Kinerja Tugas dengan Kepuasan Kerja Sebagai Variabel Intervening Pada Unit Pelaksana Teknis Daerah Surakarta". Tesis. Program Pascasarjana Universitas STIE-AUB Surakarta.

50. Winardi. 2011. Manajemen Perilaku Organisasi. Jakarta: Pustaka Binaman Presindo.

How to cite this article: Ramadhan $\mathrm{H}$, Lumbanraja P, Sinulingga S. Analysis of the effect of competence and soft skill on employee performance with job satisfaction as intervening variable at the regional social services of South Tapanuli Regency. International Journal of Research and Review. 2021; 8(8): 290-298. DOI: https://doi.org/10.52403/ijrr.20210840 